\title{
A 'Moot' for Educational Research in Europe?
}

\author{
MARIT HONEROD HOVEID \\ Norwegian University of Science and Technology, Trondheim, Norway \\ EDWIN KEINER \\ Friedrich-Alexander-universität Erlangen-Nürnberg, Germany \\ TERRI SEDDON \\ Monash University, Melbourne, Australia
}

\begin{abstract}
For many years the EERJ Roundtable has been a standing event within the European Conference on Educational Research (ECER). In a discursive style it addresses issues related to contemporary relationships between educational research and educational policy in Europe. The changing educational landscape, together with shifting practices and discourses of educational research, prompted researchers to discuss the need for increased self-governance. It was taken up as the topic for the 2013 EERJ Roundtable and couched as a question: What is the possibility of a 'moot' for educational research in Europe? This article reports on the 2013 Roundtable. Its three short presentations and subsequent audience discussion have been summarised and reflected upon to make a case for a moot: a self-governing space for educational research. It reveals ECER, and particularly the EERJ Roundtable, as a scholarly and a political arena where the interplay between research, policy and larger patterns of social change can be reviewed, interrogated and appropriated critically into the disciplinary logics of educational research.
\end{abstract}

\section{Introduction}

For many years the EERJ Roundtable has been a standing event within the European Conference on Educational Research (ECER). In a discursive style it addresses issues related to contemporary relationships between educational research and educational policy in Europe. It deals with a range of topics that are significant for educational researchers who have to navigate a research landscape that is changing rapidly alongside the processes of 'Europeanisation' that are forming 'Europe' as a supra-national regional governance structure. Reports on the Roundtable are published in the European Educational Research Journal (EERJ) and consolidate the shared wisdom of researchers as they reflect on the challenges of researching European education. Yet this history shows that it was not only Roundtable topics that were changing, but also how those topics were taken up and dealt with.

This changing educational landscape, together with shifting practices and discourses of educational research, prompted researchers to discuss the need for increased self-governance. Around 2000, this was seen as a process of researching educational research beyond national borders in the supra-national European educational research space, and also beyond European borders. One suggestion was that the European Educational Research Association (EERA) could become a kind of educational research 'observatory'. In 2008, the possibility of shared selfgovernance of educational research shifted significantly when the EERA constitution was reorganised under the German 'eingetragener Verein' (registered non-profit). EERA was formed in 1994 
as a European association of national educational research associations governed by the EERA council, comprising representatives of national or regional educational research associations. There was also a space for dialogue about educational research; a general assembly that operated as a public meeting at annual ECER conferences, but it had a low attendance rate and no decisionmaking functions. The constitutional reform disestablished the general assembly and re-constituted the annual council meeting as the highest governing structure of the association with a formal executive board.

This lost possibility of an open discursive space through EERA resurfaced earlier ideas about some kind of educational research 'observatory' with a self-governing purpose. It was taken up as the topic for the 2013 EERJ Roundtable and couched as a question: 'What is the possibility of a "moot" for educational research in Europe?". The Roundtable considered the case for an educational research moot: a space for self-governing deliberations within the European educational research community. The Roundtable was introduced by Edwin Keiner (ErlangenNürnberg) who made a case for a 'moot', building on his experience as the first convenors' representative on the EERA Council from 2003 to 2006. He elaborated the meaning of the term 'moot' as something more than a public 'forum' but less than a 'government'. A moot, he argued, was an open space where issues pertaining to educational research could be talked about, disputed, and consolidated as a shared European conversation. Marit Honerod Hoveid (Trondheim) was also a former convenor representative for three years and became Secretary General of EERA in 2012. She reflected on EERA and its history as a self-governing research association that was self-reflexive about the challenges of self-governance in the unfolding European educational research landscape. Finally, Terri Seddon (Melbourne) reflected on her 15 (out of 19) ECER conferences and the experience of flickering in and out of Europe each year. She offered a perspective on ECER as a space of dialogue and also a 'space apart' from the day-to-day routines, demands and habits of mind of her research working life in Australia. The distance, and shift from a national to an explicitly supra-national 'European' scale, made it possible to debate ways of doing education and educational research differently, even as educational policy steering veered towards instrumental ends in and beyond Europe.

This article reports on the 2013 Roundtable. Its three short presentations and subsequent audience discussion have been summarised and reflected upon to make a case for a moot: a selfgoverning space for educational research. Seddon's outside/inside perspective on travelling to ECER and her reflections on what ECER represents as a discursive arena is used in the article to give voice to ways in which ECER functions as a space for knowledge building. This is a methodological strategy that avoids artificial aggregation of ideas and insights that emerge out of different places and patterns of mobility in and through European educational research. It is further evidence of the dispersion of educational research work, identities and knowledge practices that accompany globalising policy and governance logics. It allows you, as reader, to reflect on the significance of spatialisation and mobility in educational research and how they inflect emerging forms of educational knowledge and practice. It reveals ECER and, particularly the EERJ Roundtable, as a scholarly and a political arena where the interplay between research, policy and larger patterns of social change can be reviewed, interrogated and appropriated critically into the disciplinary logics of educational research.

\section{Educational Research under Siege?}

Over the last decades educational research has more and more become a rather differentiated, even fragmented field of study. There are many partial perspectives, different theoretical and methodological approaches, various epistemological and normative grounds, intersecting networks and peer groups, and different sources, languages, infrastructural conditions and opportunities for producing and publishing educational research knowledge. These processes of fragmentation and differentiation also indicate a field of struggle and of hierarchisation. We find colonised areas, where researchers subordinate themselves under different 'mainstreams', willing to be colonised by colonising opinion leaders rather than those who might be resistant. The new managerialism contributes to a large extent by rewarding the former and marginalising the latter. As this new managerialism depends on institutional structures more then on scholarly communication, 
educational research becomes locked, and locks itself, into organisational, even national frames. The lack of big research programmes (as in psychology) and increasing competition for money to solve externally defined problems lead to an increasing fragmentation of topics, methods and networks.

At present, traditionally differentiated and ramified educational research communication is under pressure. Research management and funding arrangements steer educational research in the direction of politically desired questions and needed 'practical' and applicable research on education. The effect is to govern educational research, which raises the question to what extent we ourselves (as educational researchers) contribute to and are part of these problems.

Although educational research to a large extent still remains locked into national and cultural borders, its practice more and more becomes a European, even global, enterprise. However, the more educational research crosses borders and unlocks its particular national and cultural restrictions (and certainties), the more educational research opens up its discourses and social networks and becomes exposed as a rather unstructured, diverse open space. This space does not only provide great opportunities for the future or, euphemistically, a space of creativity and innovation. It also appears as an un-transparent space of cooperation and competition, of unequal distributions of means and power, of representing and represented participants, of actors and victims of struggle and defence.

Bourdieu's structuralist theory, especially elaborated in his Distinction: a social critique of the judgment of taste (1984), describes and explains this social structure of knowledge producers. It is an organisational order that expects others to produce knowledge, while keeping the (un-transparent) criteria for quality and value in the hands of those networks that can steer funding and management practices, and also the research questions and acceptable forms and kinds of answers. It is important to note that an ambiguous, uncertain and un-transparent concept of knowledge is useful in gaining and exerting power, because - according to organisational and management theory (Crozier \& Friedberg, 1979) - power can be defined as an ability to control uncertainty.

Education and educational research to some extent contribute to this pattern of defining adequate knowledge. First, education and its research tend to take up external expectations. Rather than breaking and redefining these expectations into the logic of work that affirms methodologically distant research knowledge, educational research shows a high ability to resonate with public and political themes (Stross \& Thiel, 1998). Yet the degree of autonomy of a scientific field is defined by its 'ability to break from external expectations or requests and turn them into a specific form that is consistent with, and constitutes, its logic of work' (Bourdieu, 1998, p. 19). The decisive indicator showing the degree of the autonomy of a research field is its breaking strength, its translation power.

Second, education and educational research does not often explicitly discuss self-governance as an academic field. This may be a consequence of tensions around the notion of 'discipline' that are driven by educational research cultures, political expectations, and research managerialism. However, this silence in the discourse of educational research displaces discussions about the nature and significance of self-governance by the educational research community, and also obscures questions about how self-governance might be directed to the public in an egalitarian, democratic sense.

In this context, one could remember the different meanings of words that - in a Habermasian sense - denote public places and spaces of deliberate discourses and unrestricted communication. The Greek had their 'agora', the Romans the 'forum', the Nordic the 'thing', the old British 'moot', and modern states 'democracy'. The word 'moot' stems etymologically from 'meeting' and to meet. It is related to assembly, court, council, synod, encounter, etc. However, these basically democratic meanings are only valid in a British cultural context. In the United States of America, the word 'moot' has a rather negative meaning as a babble, a palaver, a chatter without practical impact or relevance. In our case we definitely refer to the traditional British meaning and would be interested to learn more about equivalent words and meanings in other European languages and practices.

A series of questions arise from this background:

- Could EERA and ECERs be interpreted as a 'moot'? 
The topic for discussion at the 2013 EERJ Roundtable asked for such an open space of reflection and judgment. The structure of this space was not very clear. It was neither an ancient 'agora' or 'forum', nor a 'moot' in the British sense of a democratic, public space. It was also not a research space strictly ruled according to methodological 'gold standards'. EERA is designed as a European association of national educational research associations, but there are other European educational research associations. At the annual conference, ECER, there are large fluctuations in attendees, with some being members of a national educational research association and some of them, however, not.

- How, then, is educational research represented in Europe, and to whom does it address its conference themes and research results?

- How does educational research exert influence on research, policy and practical educational fields, and how is this influence justified and legitimised?

- Could we find or establish a discursive European educational research space, a moot, an agora, which has enough epistemological, critical and intellectual mass to go beyond the structures of organisations and managerialism, of power and governance, of rules and regulations?

Against misunderstandings, such an educational research space is not understood as a romantic garden to escape from the dirty work of everyday life. Rather, it is understood as a space that provides opportunities for critical reflection on educational research knowledge and practice, its external structures and their structuring effects, in order to strengthen self-discipline and selfgovernance. This is an educational research space that contributes to disciplinary autonomy, which a field of study gains because of its ability to translate external expectations or requests into a specific form that constitutes its logic of work.

In times of high political and financial pressure, short timelines, and low budgets, it might be more important than ever to look for, or to create, such a moot. It would offer a space where ECER participants could reflect, de-centre, and get distance on our treadmills by intensifying and dynamising an intellectual, self-governed public discourse beyond organised structures.

- But in what sense could educational researchers contribute to and influence a democratic process of Europeanisation by cultivating and caring for (Frankfurt, 1988) an open and diverse educational research moot?

\section{EERA: history of an 'observatory'}

The idea of a vibrant space for the diversity of European educational research that opens up the possibility of self-governing dialogue and its embedded logics is not new. The EERJ Roundtable was set up soon after the establishment of the EERA journal, the European Educational Research Journal (EERJ). It provided a location within the annual conference where shifting relations between research and policy, and their effects in Europeanising educational research, could be discussed. Table I lists the topics addressed during the last 10 years and shows the variety of relevant topics. Speakers who were well placed to talk about these topics were invited to provide brief comments that were subsequently published in EERJ. This organisational approach brought high-level European-global policy actors into direct dialogue with practicing researchers who experienced the sharp end of Europeanisation.

The idea of a forum for dialogue about the practice of research in educational research was discussed in 2000, at a meeting between EERA and the European Commission. One proposition was to develop an 'observatory' on educational research. From a discussion paper (Annex 10, EERA archive) [1] we can read:

Europeanization has to be a reflexive process, taken in full awareness that it reflects strong globalizing discursive practices in education as well as an opportunity to develop European antibodies and renovate older, significant practices to engage with them. We would propose that educational research should take place in an (research) Observatory structure in the EU [European Union] in which information about innovations and modernisation takes place alongside research on their significance and meaning.

The idea of this observatory was never realised. One of the reasons for this was the lack of support from the EU and maybe also because EERA was insisting on a dual purpose for the observatory. 
EERA's view was that an observatory could be an instrument for innovation, but should also allow for reflexive research on these processes to highlight their governmental significance and effects in meaning-making within the European educational research area.

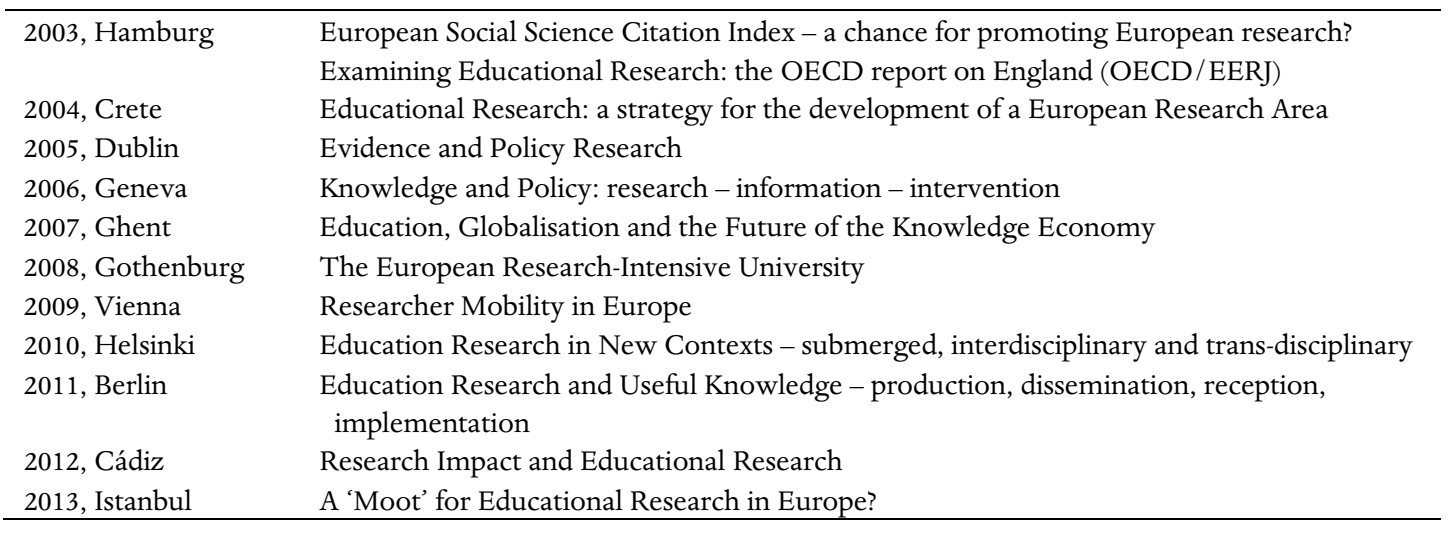

Table I. EERJ Roundtables at ECER, 2003-2013.

In this same document we can read that a subsidiary aim of this observatory was to "promote communication and exchange of focused research data between diverse geographical, intellectual and practical areas in EU/European spaces of educational research' (Annex 10, EERA Archive). While the observatory was never realised, this subsidiary aim became a defining feature of EERA and is enacted through its conference, ECER. This European educational research space has, therefore, since the inauguration of EERA in 1994, been a space where educational researchers from Europe and beyond meet, discuss and develop their research.

The idea behind EERA was to create an overarching research association embracing the wide scope of educational research. The Association was established in Strasbourg on the 18 June 1994 (Gretler, 2007). After two years of meetings and deliberations between different stakeholders educational researchers and people from the Organisation for Economic Cooperation and Development (OECD) and the EU commission - a new organisation was founded. There were initially disagreements about establishing this umbrella organisation, but once these opponents were out of the working group, a decision about establishing an umbrella organisation could be agreed.

The main idea behind EERA recognised, 'The need for a European-wide association to help researchers to coordinate their efforts in addressing current issues of education importance' (press release, EERA Archive, 18 June 1994). Within EERA, and as a means of organising the annual conference, a number of research networks were established to facilitate communication among educational researchers through a set of activities, especially the annual conference. The idea was (and still is) that this enhanced communication might lead to greater levels of coordination and collaboration among education researchers in Europe (EERA Archive).

If we take a closer look at the current 31 networks of EERA, we find a great variety in research areas represented, but also echoes of the earlier disagreements. These tensions persist, particularly, between those involved in specialised educational research associations and those involved in national educational research associations. For, as Gretler (2007, p. 3) states:

International associations specialised in sub-areas of educational research do not seem to be willing or interested in joining an umbrella organisation spanning the entire discipline ... Their general opinion was that greater specialisation in the field of educational research was necessary, rather than a broad amalgamation of the entire discipline.

Most EERA networks refer to thematic or interdisciplinary areas within education like: Teacher Education, Inclusive Education, Policy Studies and Politics of Education. There are only three networks with a disciplinary reference: History, Philosophy and Sociology of Education. In what way the current EERA networks mirror European education research is clearly debatable. For instance more psychologically informed research on education, research that traditionally was 
connected with the European Association for Research on Learning and Instruction (EARLI), is not directly represented in the EERA network structure.

The EERA network structure represents live areas of educational research amongst European educational researchers. In an organisation like EERA the networks have grown, and still are growing organically, based on research interests in the community of educational researchers. This is a crucial point in understanding the network structure of EERA, but also for understanding developments within the field of educational research. Educational research grows through the interests of engaged researchers. If research were only driven by external motivation (funding) it would probably turn into something quite dreary and unimaginative - it would become instrumental (Hoveid, 2012).

Educational research today represents a great variety of research approaches. This diversity can pose difficulties in terms of communication across different research strands. An umbrella organisation like EERA is meant to represent this diversity and ECER provides a space for meetings across cultural, language and research divides. An educational research space thought of as a 'moot' extends this idea of an open space of educational research dialogue by actively juxtaposing these different logics of educational research in meetings where ideas, ways of talking, and the practical enactment of research can be challenged and debated.

For ECER to function as a real moot, the diversity of educational research is a prerequisite. It also secures an alternative understanding of educational research that is in tension with the streamlining logics of a lot of thinking around Europeanisation from the EU and also the OECD. ECER shows that the educational research space is 'naturally' quite messy and not as orderly as some might want. It is in other words complex (Biesta, 2010). It is this complexity and not uniformity that creates 'new' approaches to education and 'new' approaches in educational research.

\section{ECER: a 'space apart' for diversity, disjuncture, detachment and distinction}

ECER is a place of dialogue where we, educational researchers, can stand apart from day-to-day managerialism and interrogate its nature and effects. ECER, in Seddon's experience, was a valuable space for knowledge building for three reasons. First ECER was a place where it was possible to develop critical concepts and vocabularies that offered ways of thinking, doing and being an educational researcher, which stood apart from the disciplining logics of emerging educational regimes. Second, the annual conference was a space of disjuncture that provided distance, making it possible to reflect on national education systems and their knowledge cultures. Finally, it was a locus of provocations underpinned by a formally constituted European Educational Research Association that also secured 'disciplinary autonomy'. These organisational arrangements legitimised ECER as a place and platform where it was possible to 'translate and break external expectations or requests into a specific form, which constitutes logic of work' (cf. Bourdieu, 1998).

Yet experiencing ECER this way depends on a particular way of being a researcher in that conference. It entails a research stance that is reflective, open to provocation, and also acutely aware and analytical about the distinctions generated through that particular 'knowledge space'. ECER is a specific ecology of knowledge and practice: a relational assembling of distinctively spatialised networks that each anchors an emergent transnational knowledge culture. Participating in ECER is what sensitised me to spatial patterns that consolidate quite specific geographies of educational knowledge and practice. These networks that become visible through ECER, and by being mapped on the EERA website, are different to those I know through Australia: my usual national knowledge culture where my working life is located and sustained by family, friends and economic resources. In this way ECER provides a counterpoint to Australia, where I most directly encounter the practical effects of libertarian mindsets that, perhaps unwittingly, are remaking education.

Encountering ECER in this mobile and reflexive way is no simple 'Eurocentrism', but a knowledge-building methodology. My methodological choice is to treat my annual reflexive movements through the knowledge space of ECER as a research process. I use ECER's transnational knowledge culture as a source of concepts, arguments and evidence that is building knowledge about education and its reform trajectories at the supra-national scale. I also use the 
emerging processes and effects of Europeanisation as a unit of reference in my research, at home and abroad. Moving back to Australia means shifting scale, re-entering a national space where I do research on Australian national educational reforms. Recognising this shift in scale explicitly means my Australian studies are premised on perpetual comparisons between the theory and practice of differently scaled educational discourses: the educational knowledge and practice of supra-national 'Europe' and, treating Australia as a particular case of contemporary educational reform, the parallel national and sub-national discourses.

These methodological innovations are only possible because ECER is organised in ways that encourage self-reflexive research. This reflexivity is directed towards the diversity of educational research across Europe, even as it is being steered and streamlined towards instrumental ends, and is also curious about the effects of Europeanisation. Turning this conference methodology into a research strategy entails three familiar research steps: observation, analysis, and dialogical refinement.

This is a research practice that must be explicit about relationalities, spatialities, and temporalities as they manifest as distinct educational and research practices and knowledge building. Seeing these patterns as particular 'ecologies of educational knowledge and practice' means becoming critically conscious of boundaries and limits. Making sense of these patterns requires further reflexivity, this time directed towards the ordering of observations and insights relative to disciplinary logics that are formalised through public discourse, which constitute the established architecture of knowledge.

'Maps' and their particular lexicons provide ways of navigating the established and emerging landscape of education and educational research at and between the supra-national and national scales. These maps of disciplined forms of reasoning, of national and sub-national territories, and of sociocultural regions and areas offer fixed 'landmarks' from which it is possible to 'see' unfolding boundary politics related to space and scale, and to grasp the geometries of power that steer and scale change towards established and emergent educational forms. Without these maps, even when they seem inaccurate or too crude, it is hard to retain any sense of orientation in the processes that are melting and re-making contemporary education through global transitions. Let me illustrate these analytical steps.

\section{Observation: ECER as theatre}

ECER offers opportunities for observations that are replete with dissonance, contradiction and spatialisation. In 2013 I attended my 15th of 19 ECERs. I make this annual visit to ECER because it is such a rich meeting place for educational and disciplinary traditions that are differently embedded in national knowledge cultures. There I watch the academic theatre as luminaries and the humble negotiate their ways of doing knowledge. They each embody national knowledge traditions and grapple with the history and theory of educational life in the places that they know.

But because ECER is not a national conference, social divisions and insider-outsider power relations are less overt than in conferences with a national research association as host. When the conference is hosted by a city there are fewer 'natives' claiming the conference space, so more people navigate ECER as 'strangers'. This levelling has effects in relationships and the way participants perform their identities. It was these relationalities that alerted me to the distinctive nature of this ECER space. I entered ECER as a stranger in a temporary workplace, an educational researcher who confronted an unfamiliar supra-national workspace: a 'place of flows' that formed as ideas and identities came together. It was a kind of bazaar, steered more by supra-national logics and designs than national conferences.

Is it these relations of familiarity and uncertainty that gives ECER its distinct kind of civility? It seems that ECER developed a culture of respectful dialogue because of its particular geography of flows. It is Eurocentric but dominated by continental rather than Anglo-American cultural traditions. Researchers 'offer' rather than assert their insights. They 'suggest' contributions to a shared intellectual project that is partly about education, and also the radically shifting spaces of national societies and their supra-national configurations. Even the attention to spoken English, the concern to regulate tempo and assertive tones, is important in this multi-lingual space. 
The theatre of ECER reveals an orientation to relationships that celebrates collaboration in ways that make space for knowledge traditions that are not historically dominant. While English is the lingua franca, native English speakers are pressed to acknowledge the divergent contributions and capacities of those whose research insights are premised on multiple translations embedded in both the knowledge and practice of Euro-English.

\section{Analysis: ECER as provocation}

Participating in ECER prompts analysis because it is necessary to make sense of what is seen, heard, smelt, and felt when passing through the conferences and their European city-spaces. These movements have strengthened my sensitivity to spatiality and how spaces are formed and are fixed through knowledge and networks.

These conceptual and epistemological insights recognise that distance is linked to culturalknowledge differences. Travelling to ECER 15 times means I have spent almost 28 days on 747 long haul flights to and from Melbourne: 22 hours there and 22 hours back. This flying time is a measure of distance, cost and culture. It reveals Australia's material affluence and cultural character that is different to that which comes into view through ECER. It highlights the value of ECER as a rich knowledge and research space. It sensitises me to differentiated geographies of knowledge and knowledge building, and also to temporal rhythms as spaces, contents, and territory are made and melt through boundary politics, the sovereign and governmental exercise of spatial powers (Seddon, 2014).

Differences in conference participant's ways of knowing the world create productive dissonances, boundaries, in ECER's cultural-knowledge landscape. Yet research 'productivity' in this space depends upon a researcher's orientation to the relations of knowledge, power and space that culture and order ECER. Early on, I met many Australians who attended one ECER, but found the conference confusing, unappealing. It seemed some only saw ECER as a 'conference' that could be compared to the American Educational Research Association (AERA) conference. Yet ECER and AERA are contextualised very differently, not just culturally, but also in terms of scale.

The dissonance between these conferences is due to horizontal divergence between national knowledge cultures, and also the scalar differences as education systems globalise. The AERA conference is nationally framed and cultured by the historic geopolitical power of US educational research. It attracts educational researchers like moths to a bright light. By contrast, ECER operates as a transnational rather than national space. It is framed by the multiple nationalities and contested relations of 'Europe', where governance is not centred by a state, but is diffracted by supra-national governance mediated through Brussels and its relationalities with sovereign 'member states'.

The 'national' scale is no longer a taken-for-granted norm that defines educational practice and knowledge building in supra-national 'Europe'. These troubling scales open up methodological choices in educational research and create provocations that generate new insights into education and educational knowledge. The re-scaling means that ECER discussions often seem different to those developing in familiar national settings.

Yet the reach of contemporary global transitions is not just restricted to Europe. It means unreflective presumptions about a national frame of reference in research are a national(ist) privilege that is increasingly unavailable to educational researchers. In recent years the number of Australian's returning annually to ECER has grown significantly. My hunch is that ECER's supranational space and culture has now become much more familiar, not just amongst those who inhabit the geography of 'Europe', but also those from nation-states, like Australia, where educational spaces are re-scaling and becoming more supra-national as ecologies of knowledge and practice.

\section{Dialogical Refinement: ECER as moot}

It is this proliferation of educational discourses within a space that cares about dialogue that makes ECER a kind of moot. It is a place where it is possible to encounter and refine hunches, ideas, and evidence. It is a 'great conversation' that generates really useful educational knowledge after the 
fragmentations of modernity when educational ecologies of knowledge and practice are being rescaled beyond the privilege of national ordering.

I find it surprising to meet researchers at ECER who are uncurious about 'ECER' itself and remain content with their national knowledge frames. They miss so much when they treat the conference as a familiar fixed landscape where they do research in their usual way. Being open to dissonance, leads quickly to questions about spatialisations, scaling and the historical unfolding of knowledge cultures and educational practices that make up distinct geographies of learning and life. Coming to understand how and why these ecologies of educational knowledge and practice unfold and are fixed by differentiated sociological, epistemological and political terms, conditions and practices is the stuff of educational research.

Moving through ECER and Australian knowledge spaces has prompted my reflections on the labour of research as a form of work. It reveals educational research as a work process that produces a particular form of narrativity (Somers, 1994). Its purpose is to construct vocabularies that best capture and convey meanings about education. Ensuring the 'best' narrativity depends on critical reflexivity within the educational research community and discussion about justifiable premises, methodological terms and conditions, and forms of evidence. It is this open dialogue that enables researchers to claim and be confident that they 'know' education.

Such reflections on methodology, representation and communication generated through ECER travel with me into my Australian research. I look for the distinctiveness of Australian educational knowledges relative to other national, supra- and sub-national spaces, and take care with my own knowledge claims and the methodological transparency of my knowledge building. Yet it seems to be increasingly difficult to find open space of dialogue about educational research at the national scale, in Australia and Europe. Policy steering is eroding the capability of educational researchers as a self-governing community of educational knowledge-builders.

Shifting scale to support a self-governing supra-national moot offers a way of re-anchoring the disciplinary logics that consolidate the educational research community as a shared conversation. A moot can help secure the sociocultural infrastructure for educational knowledge building. It makes educational knowledge more sustainable as a resource that can be transacted, rather than subsumed, by education policy makers and practitioners.

\section{Self-governing European Research: possibilities and constraints}

ECER is already a place where the supra-national educational research community is working collectively on the project of rebuilding educational knowledge for globalising times. In this knowledge building project, EERA, as an association of national educational research associations, locates, organises and legitimises the idea of an open space of educational research dialogue. This organisation creates a platform for networks to claim disciplinary and methodological autonomy by clarifying their academic and educational logics through dialogue, unfettered by the duties that wait at the national scale. Yet can ECER also locate a moot: a place of meetings where ideas, ways of talking, and practical enactment of research can be challenged, named and claimed?

Foregrounding ECER as moot would, we suggest, mean creating spaces that go beyond dialogue, active debate, and open up deliberations about shared research conventions. Their development through 'Europe' would distinguish 'European' educational research as an emergent space-time and a specifically scaled case of educational knowledge and practice in globalising transitions. The history of EERA suggests that these conventions would not be rules defined topdown, but understandings that a self-governing educational research community might generate to secure its knowledge-building practice and sustain its disciplinary autonomy.

With hindsight, the 2013 EERJ Roundtable and the discussion it provoked, suggest five conventions that may warrant further reflection in a self-governing research community. We illustrate them by drawing on the audience discussion to highlight the possibilities and dilemmas they present in this call for a moot in European educational research. 
1. Global Transitions: recognising space, time, scale and the educational effects of boundaries

Istanbul, the location of ECER 2013, was a reminder that space, time, scale and boundary making have powerful effects on education and educational research. It is the city where East and West meet, where Europe confronts Asia. These historic boundaries are evidence of powers that delineate spaces socially and culturally, and how they create divisions and constraints on movements and knowledge building. So what is EERA's outlook regarding linkages to the rest of the world? India, Algeria, etc. are all in a way a part of Europe due to long periods as colonies. So 'Europe' is more a habit, an attitude or mindset, than a territory. Limiting European educational research to Europe's politically defined boundaries limits educational knowledge building.

The challenges facing educational research apply around the world, but the effects of European boundary making offers some lessons for educational research. 'Europe' has opened up boundaries and one consequence is that universities are not the only place where research takes place. Universities at the national scale are not only sources of knowledge, but are also subject to more inputs and claims about knowing education. So what makes our (university) research different? What gives us our distinction, nationally and as a supra-national European educational research space? How do we avoid having research taken out of our hands?

These questions open up discussions about the nature of boundaries and limits in educational research, how they are made and who defines them. Before 'Europe' and its Bologna agenda opened up the boundaries of universities as institutions of knowledge at the national scale, educational research operated as a field made up of groups centred by small projects (just like the composition of Europe). Now these small fora are pressed to relate to the outer world - not just to North America and Europe, but also towards Asia, to the global South, as well as the global North. But small groups have limits, even though the energy and diversity of the small projects is a key indicator of the health of educational research. It is this mixture that gives educational knowledge life and capacities for renewal.

\section{Methodological Choices: from territorialised research to self-governing conversations}

The effects of policy steering of educational research are also significant for the educational research community. Instrumental policy steering, competition for funding and pressures to publish (or perish) disrupt established ways of working. Competing behaviour creates divisions between professors and researchers, and can produce disrespectful attitudes between strands of research. This divided landscape challenges all researchers but, particularly, those who are emerging researchers, do not work within the territorial boundaries of Europe, or work with unconventional theory frames. They already feel like 'outsiders' but must navigate the conference when their fundamental question is 'where are we in?'.

Understanding these boundary effects and how they are endorsed and ameliorated through governance processes offers ways of addressing these competitive pressures. Investing more time and energy in cooperating and helping each other can help to build a culture of cooperation. Cooperation, rather than competition, is another solution for educational research when funding is being cut. Because these funding cuts go beyond educational research, there are possibilities for collaboration with others, for example in social science research, and through induction of emerging researchers. These strategies offer ways of securing educational knowledge traditions through relationships that do not just depend upon research funding, but also require selective shifts in the permeability of boundaries.

Collaborations and cooperation encourage shared conversation but also present dilemmas in an educational research community with diverse cultures. Doing research means engaging with educational policy debates and power discourses, and also working between research cultures to find an aggregated common voice. The common voice may offer ways of steering funding towards educational research, and can be democratically more efficient by bringing in new people and stakeholders. But a common voice can over-aggregate the discourse, undercutting specialist lexicons and knowledge practices, as well as creating problems of integration and exclusion: who is in, and who is out, how, and why? 


\section{Units of Reference: identifying shared navigational landmarks, maps and terminologies}

A 'common voice' rests on choices about where is 'common' and where is 'different', and how commonalities and differences are scaled, sequenced and directed across specific space-times. 'A 'heart attack' is the same in every language in Europe. This commonality of terminology that speaks to everybody's personal experience of health and death provides a powerful impetus for research and research investments. But 'education' is a complicated reference point in educational research. We may speak of 'education' using the same words, but they mean different things in, for example, France or Germany. ECER is a good forum for recognising these differences between words but understanding what the words mean depends on dialogue and sophisticated processes of cultural historical translation (Nóvoa \& Yariv-Marshal, 2003). This is research, but it requires agreements about points of departure, reference societies, and terminologies.

Words at ECER are difficult because of the multi-layered aspect, but they are also generative, prompting sophisticated work on their educational and social translation. Certain ECER rules (e.g. three countries in a symposium) encourage dissonance and help to make cultural differences in terminologies and habits of mind explicit. This dissonance inspires discussions that build shared meanings at a supra-national scale, while continuing to acknowledge the persistence of words and meanings that reflect particular educational dialects at the national scale. This consolidation of vocabularies is important work at ECER because consolidated vocabularies can travel beyond the conference and become resources for educational policy and research dialogues across other spacetimes.

\section{Public Spaces and Publication Repositories: venues for deliberation and making public discourse public}

One way of addressing the dilemmas between common voice and different cultures is to clarify the rules governing boundaries and how they make and work in spaces. EERA rules grew organically through small project groups and subsequently formalised EERA networks, but transparency remains a practical challenge. While procedures are clearly defined on the EERA website, each person reads and perceives them differently. The key principle is that EERA endorses the organic growth of educational research ecologies of knowledge and practice, even though these formative processes shift over time. Recognising the diversity of researchers at ECER and the scope for unintended exclusionary effects, justifies experiments that address transparency by more actively inducting researchers into EERA. For example, having the EERJ Roundtable or another 'moot' on the Tuesday of the ECER conference week creates a bridge between the emerging researchers and main conference. Inviting network convenors to talk about their networks in terms of their shared projects, with open questions from the audience, might help to strengthen shared understandings about networks and their educational research logics.

The question in organising this scientific research labour is how boundaries and processes are managed to secure appropriate degrees of openness and closure around knowledge building. Yet this boundary making can become contentious. Opening up spaces of dialogue when governing protocols are not understood or adhered to, or closing them off to researchers with legitimate scientific positions, threatens the legitimacy of the science as well as its researcher communities. This is well illustrated in climate change science, where distinguishing climate science and climate scepticism depends upon shared understandings about careful peer review governed by explicit scientific objectives (e.g. Stokstad, 2014).

Yet opening up boundaries can also facilitate fruitful integration of governance and induction. For example, fields of research claiming the status of 'science' often work through multi-authored articles where senior and junior researchers negotiate insights, novelties, evidence, and wisdom in knowledge-building processes. Review processes open up further dialogical spaces where research and findings can be subject to active scrutiny and dialogue, building knowledge and also consolidating particular disciplinary logics and norms. The European Geosciences Union, for example, publishes Atmospheric Chemistry and Physics [2] in two formats: a pre-publication interactive peer-review discussion journal and the core journal where fully peer-reviewed articles are subsequently published. Both formats are publicly available, but readers know the research protocols that govern each. 
5. Educational Knowledge Politics: grasping disciplinary

autonomy and its endorsed logics as a field of educational research

The challenges facing educational research and responses emerging through the supra-national 'Europe' are remaking methodological choices that define how we do our research. In these terms and conditions of research work, it takes courage to behave scientifically. But courage is a collective rather than individual characteristic. Cooperation and collaboration helps when boundary processes are governed by protocols that develop organically and become widely understood and agreed by the field. Educational researcher communities can provide these supports through organisations and governance practices that legitimise and scale particular research questions, methodologies and deliberative accountabilities.

For EERA, the question is how to have a governance process that secures the distinctive cultural achievements evident with ECER, but is also open to difference and novelty. The strategy that seems to be emerging links governance and induction: it combines deliberative rule making that governs particular finite space-times and scales, but also actively encourages the temporal development of expertise and confidence amongst research identities. A 'moot' offers this kind of cultural induction, and also serves as a locus for discussing where 'common voice' in the European educational research space is useful and where it is not.

Such deliberative governance can influence political discourse and action, for example, addressing ways of speaking coherently about, and to, the two sides of the 'Bosporus': education and research. Organisations without education in their title do education and are involved in educational research. But there are also 75 million students and 20 million teachers, and this huge industry has immense power because it develops habits of mind amongst lifelong learners, workers and citizens, into the future. Tapping into this politics of knowledge means moving away from selflimiting ideas about our collective self as educational researchers. It means recognising that research creates vocabularies that make educational policy and practice possible, at and across scales. These understandings raise questions about responsibility, influence, effects and authority: the issues with which climate scientists now grapple.

EERA is a place where we can, and do, construct a European research identity and a European educational research area. A 'moot' provides the open space of dialogue that sustains wisdom and novelty in a culture of renewal. It is not just about established researchers having more power, but also about including new researchers: researchers who are 'emerging', 'moving' across conventional boundaries that delineate territories, social stratifications, and language communities, and 're-scaling' the analytical frames that govern their educational research. A moot through EERA offers ways of addressing the re-scaling of education and the educational research community, but without losing the project of knowledge building in, through, for, and about education.

\section{Notes}

[1] The EERA archive is not open to public access. It is stored at the EERA office in Berlin. Some of the material from this archive will be published through an online exhibition in commemoration of EERA's twentieth anniversary.

[2] The Atmospheric Chemistry and Physics is available at: http:/ / www.atmospheric-chemistry-andphysics.net/ (accessed February 7, 2014).

\section{References}

Biesta, G. (2010) Five Theses on Complexity Reduction and its Politics, in D. Osberg \& G. Biesta (Eds) Complexity Theory and the Politics of Education, pp. 5-14. Rotterdam: Sense.

Bourdieu, P. (1984) Distinction: a social critique of the judgment of taste. London: Routledge.

Bourdieu, P. (1998) Vom Gebrauch der Wissenschaft. Für eine klinische Soziologie des wissenschaftlichen Feldes. Konstanz: Universitätsverlag Konstanz.

Crozier, M. \& Friedberg, E. (1979) Die Zwänge kollektiven Handelns. Über Macht und Organisation. Königstein im Ts: Athenäum. 
Frankfurt, H.G. (1988) The Importance of What We Care About. Cambridge: Cambridge University Press. http: / / dx.doi.org/10.1017/CBO9780511818172

Gretler, A. (2007) The International Social Organisation of Educational Research in Europe: reviewing the European Educational Research Association as an example - facts and questions, European Educational Research Journal, 6(2), 174-189. http:/ / dx.doi.org/10.2304/ eerj.2007.6.2.174

Hoveid, M.H. (2012) Educational Research and Useful Knowledge: production, dissemination, reception, implementation, European Educational Research Journal, 11(1), 58-61. http: / / dx.doi.org/10.2304/ eerj.2012.11.1.58

Nóvoa, A. \& Yariv-Marshal, T. (2003) Comparative Research in Education: a mode of governance or a historical journey?, Comparative Education, 39(4), 423-438. http: / / dx.doi.org/10.1080/0305006032000162002

Seddon, T. (2014) Making Educational Spaces through Boundary Work: territorialisation and 'boundarying', Globalisation, Societies and Education, 12(1), 1-22. http:/ / dx.doi.org/10.1080/14767724.2013.858396

Somers, M.R. (1994) The Narrative Constitution of Identity: a relational and network approach, Theory and Society, 23, 605-649. http:/ / dx.doi.org/10.1007/BF00992905

Stokstad, E. (2014) Alleging 'Malpractice' with Climate Skeptic Papers, Publisher Kills Journal. Science, January 17. http:/ / dx.doi.org/10.1126/science.343.6166.17

Stross, A.M. \& Thiel, F. (1998) Themenkonjunkturen und Disziplinentwicklung. Eine Untersuchung erziehungswissenschaftlicher Zeitschriftenbeiträge 1987-1994, in A.M. Stross \& F. Thiel (Eds) Erziehungswissenschaft, Nachbardisziplinen und Öffentlichkeit. Themenfelder und Themenrezeption der allgemeinen Pädagogik in den achtziger und neunziger Jahren, pp. 9-32. Weinheim: Beltz.

MARIT HONEROD HOVEID is an Associate Professor of Pedagogy at the Department of Education (Pedagogisk Institutt) at the Norwegian University of Science and Technology in Trondheim, Norway. She served as a network representative on the EERA Council from 2008 to 2011 and is the elected Secretary General of EERA from 2012, serving for a four-year period. Her research interests are primarily about the relationship between teaching and learning and how we can understand learning processes not merely as an individual undertaking but as something which is influenced by and embedded in social and cultural contexts. Recurrent themes in her research are mentoring/counselling, leadership and organisational development in education. Correspondence: marit.hoveid@svt.ntnu.no

EDWIN KEINER is a Professor of Foundations of Education (Allgemeine Erziehungswissenschaft) at Friedrich-Alexander-Universität Erlangen-Nürnberg, Germany. He was the first conveners' representative on the EERA Council from 2003 to 2006, and he has been the chairperson of the commission of 'Research on Educational Research' (Wissenschaftsforschung) and of the section 'Foundations of Education' of the German Educational Research Association for many years. His fields of investigation include comparative history and sociology of education and education research in Europe; and technological, epistemological and social conditions regarding the production, distribution, reception and application of education research knowledge. Correspondence: edwin.keiner@fau.de

TERRI SEDDON is a Professor of Education at Monash University, Melbourne, Australia. She investigates the educational effects of global transitions. She examines education policies and policy effects that disturb workplaces and the way educators engage with knowledge and practice to support adult learning, leadership, and innovation and change. This approach provides a window on continuities and change in educational governance and its implications for remaking education, research and educational work. Correspondence: terri.seddon@education.monash.edu.au 